\title{
ANSERJ
}

Vol. 12, No. 2

Autumn / automne 2021

pp. $8-12$

Canadian Journal of Nonprofit and Social Economy Research

Revue canadienne de recherche sur les OSBL et l'économie sociale

\section{Does COVID-19 Portend a Shocking Future for Nonprofits?}

\author{
John R. Whitman \\ Harvard University Extension School
}

\begin{abstract}
COVID-19 caught many nonprofit leaders by surprise. The impact of the pandemic was unprecedented in recent history. Has this shock provided a wake-up call for nonprofits to better prepare for possible future shocks, notably those related to climate change? This article presents a number of questions that have emerged from the COVID-19 experience, provides several sources of guidance on preparedness planning, and notes the opportunity for new courses to address leadership needs for preparedness.

\section{RÉSUMÉ}

La COVID-19 a pris plusieurs dirigeants d'OSBL par surprise. Après tout, l'impact de la pandémie s'est avéré sans précédent dans l'histoire récente. Ce choc a-t-il pu servir d'avertissement aux OSBL afin qu'ils soient mieux préparés pour de futurs chocs possibles, notamment en ce qui a trait au changement climatique? Cet article soulève maintes questions provenant de l'expérience de la COVID-19, offre plusieurs sources de conseils sur la planification préalable, et souligne l'opportunité de créer de nouvelles approches pour combler les besoins en leadership afin d'assurer une meilleure préparation en vue de chocs futurs.
\end{abstract}

Keywords / Mots clés: Nonprofit management; Strategic planning; Shock / Gestion d'OSBL; Planification stratégique; Choc

\section{INTRODUCTION}

Many executive directors of nonprofit organizations may forever recall a vivid sense of panic when the COVID-19 emergency was announced in 2020. Despite years or decades of reliably providing critical services to those in need, the delivery of face-to-face care was suddenly entirely off the table.

Was, or is, COVID-19 a harbinger of more shocks to come? To contemplate this, recall the immediate impact of COVID-19. It galloped in on a global scale as pestilence, the threat of hunger, if not famine, soon followed, ineluctably trailed by death. The pandemic, which is by no means over yet, caused an initial shock in the United States, one of the world's most robust economies, that exceeded the upheaval of the Great Recession, comparable only to the Great Depression in terms of economic upheaval, businesses closings, particularly small businesses, and the loss of jobs, particularly 


\section{Whitman (2021)}

among those with low incomes (Baker, Bloom, Davis, Kost, Sammon, \& Viratyosin, 2020; Fairlie, 2020; Parker, Minkin, \& Bennett, 2020).

According to the Johns Hopkins Center for Civil Society Studies, the nonprofit sector in the United States lost seven percent of its workforce in the first year of COVID-19 (Newhouse, 2021a), and the estimated time to recover was two years from February 2021 (Newhouse, 2021b). Hunger in the United States had reached a 20-year low just prior to COVID-19, but the combined forces of poverty and unemployment, which spiked with the onset of the pandemic, meant that 42 million people in the country, including 13 million children, could face food insecurity in 2021 (Feeding America, 2021). That is 10 percent more food-insecure people than the entire population of Canada!

With deaths now approaching 800,000, the United States has not experienced such massive mortality since the 620,000 lives lost in its self-inflicted Civil War. Canada has sadly lost nearly 29,000 souls. Comparatively, as of the end of November 2021, Canada has lost 789 lives per million; the U.S. has lost 2,352 per million (Statista, 2021).

Despite the disparities between the two countries, and the greater impact on the United States likely due in part to idiosyncratic beliefs among its population (Vitriol \& Marsh, 2021), nonprofit organizations, whether engaged in providing amenities, such as museums and symphonies, or services, such as childcare and hunger relief, are similarly threatened by COVID-19 in at least two important ways. First, the behavioral change of social distancing, adopted voluntarily even prior to mandates, disrupts the ability to conduct business as usual. While museums, performing arts organizations, and other cultural nonprofits had to shutter indefinitely (or some permanently), other organizations found work-arounds by arranging curbside pickup of books at libraries, depositing food boxes in the trunks of cars, and a converting to online learning at schools on a massive scale (Whitman, Janicki, \& Visser, 2020).

Second, the disease itself had a direct impact on organizations, for example, by causing volunteers, especially the elderly, to stop contributing out of fear of infection, by creating sudden losses of workers due to infection and death, and by increasing the number of vulnerable people requiring critical services delivered only through nonprofit organizations. The shortage of beds at hospitals in the United States reached crisis proportions, forcing hard decisions, and the stress on medical staff resulted in unusual levels of burnout and resignations.

\section{REFLECTION AND RESILIENCE}

What have we learned? And what can we continue to learn? The deluge of publications and perhaps even creative arts in response to these questions is just beginning. But it is not unreasonable to expect that additional shocks of this magnitude will be forthcoming. Regardless of the ultimately settled etiology of COVID-19, it is now beyond doubt that those who forecasted pandemics long prior to this one were, and continue to be, absolutely correct. Surely more pandemics can be expected. Moreover, climate change will itself create additional varieties of shocks, including drought-caused famines, extreme natural disasters, and the expansion of areas susceptible to serious disease vectors. And if a recent report from the U.S. intelligence community and the Pentagon is correct [National Intelligence Council, 2021], climate change may yet unleash the fourth horseman: war. So, the right answer to the title of this piece is "yes."

Beyond agreement that future shocks are immanent in a changing global climate, how can nonprofits better prepare? The mot du jour in response is resilience. A recent book, The Resilient Society, by Princeton economist Markus Brunnermeier (2021) makes a helpful distinction between resilience, the ability to rebound, and robustness, the ability to resist. The author recounts a poem by Jean de La Fontaine called "The Oak and the Reed":

The oak is robust. It is mighty and looks indestructible in the face of normal winds. By contrast, the reed is resilient.

Even light breezes bend the reed. But when a strong storm erupts, the reed declares: "I bend but do not break." (p. 2) 
Resilience, argues the author, may not be the most efficient option and, rather, may require redundancies to serve as buffers, or backups, in times of shock. He also notes that resilience is related to sustainability, the capacity to operate for the long run. But these features appear contrary to what has been expected of nonprofits to date. Nonprofits have long been admonished to be efficient and to pass the maximum possible amount of resources onto the populations they serve. Not surprisingly, there is an ongoing exhortation for sufficient overhead funding merely to be able to continue to serve the populations of concern to funders.

Christian Seelos and Johanna Mair (2017) advise in their book, Innovation and Scaling for Impact, that more vulnerable nonprofits would do well to focus on building and strengthening their business model and then scaling to build the heft required to be able to innovate to develop resilience. In the United States, the vast majority of nonprofits constitute a long tail of organizations with limited resources or virtually no revenues to report. In times of shock, the most bereft of these ironically may suffer the least effect because, to quote Nobel laureate Bob Dylan from his Highway 61 Revisited album, "when you ain't got nothing, you got nothing to lose." But for others more susceptible to shock, perhaps now is the time to consider building resilience through federating with like entities, engaging in strategic alliances, or even merging to create the bulk required for sustainability. And, no doubt, with new threats, new types of nonprofits might emerge to meet needs not adequately met by government, the market, nor other nonprofits.

A timely article in Foreign Affairs by J. Peter Scoblic and Philip E. Tetlock (2020), considered the "right way to think about the future" (p. x), which then led to discovering the work of George Cairns and George Wright (2018), embodied in their book Scenario Thinking: Preparing Your Organization for the Future in an Unpredictable World. Scenario thinking, as described, is a methodology to help organizational leaders imagine plausible future worlds and then plan accordingly.

\section{REVISIONING}

Some plausible scenarios to contemplate come immediately to mind. For example, we need to critically consider the role and stability of social institutions. Institutions such as the church, the government, the law, the military, and even public charity, consisting of nonprofit organizations, have evolved principally to provide stability, continuity, and protection for societies. These institutions have evolved over the past 10,000 years of civilization during a time of climate stability following the last ice age. But since the climate is now changing, perhaps poised to cause unprecedented social dislocations, it is not yet clear what the strain will be on institutions we take for granted. Could drought and extreme natural disasters create untenable expectations of underfunded governments to respond with assistance? Will decades of starving governments of tax revenues leave them in a compromised situation? In relatively good times, the level of social funding provided by private individuals and philanthropy has only amounted to about $\$ 400$ billion dollars-seven percent of the entire federal budget of \$6.6 trillion in 2020 —or less than what the United States federal government provides for Medicaid. There is no way that individuals or the private sector will be able to pay for the consequences of climate change. And yet the United States already has a $\$ 28$ trillion debt, leaving it quite vulnerable to future shocks. Many cities are facing similar fiscal woes.

In short, a number of important questions have emerged from COVID-19:

- Is preparedness the new overhead fight?

- Should funders require a resilience metric?

- Should boards require scenario thinking and planning?

- Should more nonprofits federate? Develop alliances? Merge?

- Should nonprofits negotiate pre-disaster response plans with local governments?

- Should the private sector (by sector) initiate its own reserves for nonprofit resilience? 
Whitman (2021)

- Will an account of how an executive director responded to COVID-19 be part of future job interviews?

Perhaps most difficult but also most promising, should nonprofits start a social movement (in the United States) to demand greater social resilience through government policies requiring inter alia a minimum livable wage, single-payer universal healthcare, housing as a right, and minimum nutrition as a right? If so, how will such guarantees be funded?

\section{RESEARCH AND LEARNING}

These questions require further research. Indeed, these and other questions may well constitute substantive topics for exploration and deliberation in educational courses that may emerge in the shockwaves of COVID-19's aftermath. Among new courses designed to help nonprofit leaders plan for future shocks is Innovations in Nonprofit Management, available through the Harvard University Extension School.

Because there remains much to research and learn about how to prepare for future shocks such as COVID-19, courses such as this should both contribute to empowering leaders to prepare for the future and, through co-creation among participants, yield new findings and perhaps methodologies for building needed resilience.

\section{REFERENCES}

Baker, S.R., Bloom, N., Davis, S.J., Kost, K.J., Sammon, M.C., \& Viratyosin, T. (2020). The unprecedented stock market impact of COVID-19. Cambridge, MA: National Bureau of Economic Research. URL: https://www.nber.org /papers/w26945 [August 19, 2020].

Brunnermeier, M.K. (2021). The resilient society. Colorado Springs, CO: Endeavor Literary Press.

Cairns, G., \& Wright, G. (2018). Scenario thinking: Preparing your organization for the future in an unpredictable world. Cham, $\mathrm{CH}$ : Palgrave Macmillan, Springer Nature.

Fairlie, R.W. (2020). The impact of COVID-19 on small business owners: The first three monghts after social-distancing restrictions. Cambridge, MA: National Bureau of Economic Research. URL: https://www.nber.org/papers/w27462.pdf [September 17, 2020].

Feeding America. (2021). The impact of the coronavirus on food insecurity in 2020 \& 2021. URL: https://www.feeding america.org/sites/default/files/2021-03/National\%20Projections\%20Brief_3.9.2021_0.pdf [October 25, 2021].

National Intelligence Council. (2021). National Intelligence Estimate: Climate change and international responses increasing challenges to US national security through 2040, document number NIC-NIE-2021-10030-A. Office of the Director of National Intelligence, Washington, DC.

Newhouse, C. (2021a). COVID-19 jobs update, February 2021: Nonprofit sector lost over 7\% of its workforce in the first year of the pandemic. Center for Civil Society Studies. URL: http://ccss.jhu.edu/february-2021-jobs/ [October 25, 2021].

Newhouse, C. (2021b). COVID-19 jobs update, January 2021: Nonprofit jobs still down by nearly 960,000 as of January, time to full recovery increases to 2 years. Center for Civil Society Studies. URL: http://ccss.jhu.edu ljanuary-2021-jobs/ [October 25, 2021].

Parker, K., Minkin, R., \& Bennett, J. (2020). Economic fallout from COVID-19 continues to hit lower-income Americans the hardest. Washington, DC: Pew Research Center. URL: https://www.pewresearch.org/social-trends/2020/09/24 leconomic-fallout-from-covid-19-continues-to-hit-lower-income-americans-the-hardest/ [October 25, 2021].

Scoblic, J.P., \& Tetlock, P.E. (2020). A better crystal ball: The right way to think about the future. Foreign Affairs, 99(6), 10-18.

Seelos, C., \& Mair, J. (2017). Innovation and scaling for impact: How effective social enterprises do it. Stanford, CA: Stanford Business Books. 
Statista. (2021). COVID-19 cases and deaths per million in 206 countries as of October 25, 2021. Brooklyn, NY:

Stasista. URL: https://www.statista.com/statistics/1104709/coronavirus-deaths-worldwide-per-million-inhabitants/ [October 25, 2021].

Vitriol, J.A., \& Marsh, J.K. (2021). A pendemic of misbelief: How beliefs promote or undermine COVID-19 mitigation.

Frontiers in Political Science, 3(June 2021). URL: https://www.frontiersin.org/articles/10.3389/fpos.2021.648082/full [October 25, 2021].

Whitman, J.R., Janicki, M., \& Visser, M. (2020). Open to change: Libraries catalyze small business adaption to COVID-19. Washington, DC: American Library Association. URL: http://www.ala.org/advocacy/sites/ala.org.advocacy/files /content/Workforce/LBB_PP\%20-\%20final.pdf [November 11, 2020].

\section{ABOUT THE AUTHOR/L'AUTEUR}

John R. Whitman is Instructor at Harvard Extension School. Email: johnrwhitman@mac.com . 